\title{
Effect of Crude Oil Pollution on some Soil Physical Properties
}

\author{
Ewetola E. Abosede \\ Department of Crop Production and Soil Science Ladoke Akintola University of Technology, P.M.B 4000, \\ Ogbomoso, Oyo State, Nigeria.
}

\begin{abstract}
The release of crude oil into the environment by oil spills is receiving worldwide attention due to the potential risks posed to the ecosystem. The effect of crude oil pollution on soil physical properties was investigated at Effunrun, Warri, Delta State, Nigeria. Soil samples in three replicates were collected from a polluted area and control (unpolluted) sites at three soil depths of $0-5 \mathrm{~cm}, 0-10 \mathrm{~cm}$ and $10-15 \mathrm{~cm}$ and analyzed for soil physical properties. Sand particles was significantly $(p<0.05)$ reduced by $4.4 \%$ at $10-15 \mathrm{~cm}$ depth when compared with $0-5 \mathrm{~cm}$ depth. In contrast, clay content was significantly $(p<0.05)$ lower at $0-5 \mathrm{~cm}$ depth than 5 $10 \mathrm{~cm}$ and $10-15 \mathrm{~cm}$ respectively, by $26.0 \%$ and $30.7 \%$. Clay content increased with soil depth. Soil total porosity and macroporosity were $7.84 \%$ and $17.6 \%$, respectively being higher in unpolluted soil than polluted soil howbeit, the results were similar. The study revealed that crude oil can have effect on pore spaces within the soil. Consequently, this may impair aeration and infiltration of water into the soil and inhibit plant growth.

Keywords: Crude oil, Pollution, Soil, Physical properties, Ecosystem
\end{abstract}

\section{Introduction}

Pollution of the environment is one of the major effects of human technological advancement. It results when a change in the environment harmfully affects the quality of human life including effects on animals, micro organisms and plants. Therefore, [1] defined soil pollution as the appearance in soils of persistent toxic compounds, chemicals, salts, radioactive materials, or disease causing agents, which have adverse effects on plant growth and animal health. The contamination of the environment (mainly terrestrial and aquatic) by crude oil is referred to as crude oil pollution and it is estimated that $80 \%$ of crude oil pollution is as a result of spillage [2].

Currently, about $80 \%$ of land are polluted by products of petroleum origin (hydrocarbons, solvent, etc.) used as an energy source in the oil industry, as well as chemicals [3]. There are a variety of pollutants affecting topsoil and subsoil, such as fuel and oil products, hydrocarbon residues, crude oil, other products resulting from the operation (saturated and unsaturated aliphatic hydrocarbons, and the monocyclic and polyclic aromatic) [4].

Nigeria still depends largely on crude oil for income earnings. Crude oil which is abundantly located in the Niger Delta region of Nigeria is spilled on soil due to pipeline destruction [5]. Previous studies on crude oil pollution in soil had revealed its adverse effects on soil productivity [6,7]. These studies had been majorly on the effects of pollution on chemical properties of the soil. There is therefore a need for continuous research on the problems associated with pollution resulting from spillage and the effects on the soil environment which has a negative impact on crops grown on it.

As a result of crude oil pollution, soil physical properties such as pore spaces might be clogged which reduces soil aeration, infiltration of water into the soil, increased bulk density of the soil which may affect plant growth. Crude oil which is denser than water may reduce and restrict permeability. Some of the effects of crude oil may have adverse effects on soil physical properties include decreased pore spaces, saturated hydraulic conductivity and increased bulk density. All these possibilities deserve empirical studies to establish their reality or otherwise. Therefore, this particular study had its main objective to examine the effects of crude oil pollution on soil physical properties.

\subsection{Experimental site:}

\section{Materials and Methods}

The experiment was carried out along PPMC Warri-Kaduna Crude Oil Pipeline spill site near Effurun Round about, Warri, Delta State.

\subsection{Soil sampling and Laboratory analysis:}

Soil samples were collected from the polluted and unpolluted sites using $98 \mathrm{~cm}^{3}$ soil cores for each site. Three core samples, $0-5 \mathrm{~cm}, 5-10 \mathrm{~cm}$, and $10-15 \mathrm{~cm}$ were collected in three replicates from both sites and analyzed for physical parameters. Particle size distribution was determined by calculating percentage of sand, silt and clay using hydrometer method [8]. Saturated hydraulic conductivity (Ksat) was determined by maintaining a constant head of water above undisturbed core [9]. A flask of water was inverted above the core 
containing water in order to maintain constant head of water. The quantity of water (Q) drained in every 5 minutes was measured until equilibrium (constant volume of water) is reached.

$\mathrm{Ks}=\mathrm{QL} /[\mathrm{At}(\mathrm{H}+\mathrm{L})]$

$\mathrm{Ks} \quad=$ Saturated hydraulic conductivity

$\mathrm{Q} \quad=$ volume of water passing through the soil column $\left(\mathrm{cm}^{3}\right)$.

$\mathrm{L} \quad=$ Length of the soil column $(\mathrm{cm})$

A $=$ Cross sectional area through which the flow takes place $\left(\mathrm{cm}^{2}\right)$

$(\mathrm{H}+\mathrm{L})=$ Hydraulic head difference between the inlet and outlet ends of the column.

$\mathrm{t} \quad=$ time (seconds)

Bulk density was estimated by dividing the oven-dry mass of the soil by the volume of the soil as described by [10]. This was computed by dividing the oven-dry mass of the soil by the volume of the core.

Pore size distribution was calculated using the water retention data and capillary rise equation as described by [11]. Macropores (pores $>30 \mu \mathrm{m}$ ), taken as drain pores were estimated at $10 \mathrm{kPa}$ matric potential. Total porosity (TP) was calculated from the parameters of bulk density and particle density using an assumed value of $2.65 \mathrm{~g} / \mathrm{cm}^{3}$ for particle density in the formula:

$\% \mathrm{TP}=1-(\mathrm{Pb} / \mathrm{Ps}) \times 100$

Where $\mathrm{Pb}$ is the bulk density and $\mathrm{Ps}$ is the particle density.

\subsection{Statistical Concepts and Analysis of Experimental Data}

The experiment was a split plot in a Randomized Complete Block Design (RCBD) with main treatment as pollution and sub-plot as depths of soil sampling. The treatments were replicated three times. All data obtained were fitted into general linear model, while treatment effects were compared using analysis of variance. Least Significant Difference (LSD) was used to compare the means [12].

\section{Result and Discussion}

\subsection{Effect of pollution on particle size distribution of the soil at different depths}

Particle size distribution of the soil samples from polluted and unpolluted soils at various depths are presented in (Table 1).

Sand (2-0.02 $\mathrm{mm}$ in diameter): Crude oil pollution had no significant influence on sand particles (Table 1). However, depth of soil sampling significantly $(\mathrm{p}<0.05)$ influenced sand particles at $10-15 \mathrm{~cm}$ depth. Sand particles was significantly higher at $0-5 \mathrm{~cm}$ depth than and $10-15 \mathrm{~cm}$ by $4.35 \%$. It is important to note that sand proportion remained the same for both polluted and unpolluted soil, suggesting that crude oil pollution did not alter sand percentage except at 10-15 cm depth. Similarly, [3] reported no significant result in crude oil pollution on granulometric fraction of the soil.

Silt (0.002-0.002 $\mathrm{mm}$ in diameter): The presence or absence of crude oil in the soil did not affect silt content of the soil at 0-5, 5-10 and 10-15 cm soil depth (Table 1). A similar result was obtained by [3] who observed in a crude oil polluted area that granulometric fraction of the soil was not influenced by the presence of crude oil.

Clay particles $(<0.002 \mathrm{~mm}$ in diameter): Crude oil pollution did not significantly influenced clay size particles (Table1). However, depth of soil sampling significantly $(\mathrm{p}<0.05)$ influenced clay particles. Clay particles was significantly $(\mathrm{p}<0.05)$ lower at $0-5 \mathrm{~cm}$ than $5-10 \mathrm{~cm}$ and $10-5 \mathrm{~cm}$ depths respectively, by $26.0 \%$ and $30.7 \%$. This may be attributed to movement of clay particles from $0-5 \mathrm{~cm}$ which is later deposited at $5-10$ and $10-15 \mathrm{~cm}$ soil depths. Similar report was obtained by Marinescu et al. (2011) who observed no differences in clay fraction between polluted and unpolluted soils.

\subsection{Effect of pollution on other physical properties of the soil at different depths}

Saturated hydraulic conductivity (Ks) and Water holding capacity (w. h. c): Crude oil pollution had no significant effect on Ks and w.h.c at various sampling depths (Table 2). Although, the result was statistically similar, there was appreciable decrease in Ks and w. h. $\mathrm{c}$ with depths of soil sampling. This result may be due to the blockage of the pore with the pollutant.

Bulk density and total porosity: The presence of crude oil did not have significant influence on bulk density and total porosity at different depths (Table 2). Despite the similar result, when unpolluted soil (control) was compared with polluted soils, bulk density increased by $7.1 \%$ and total porosity reduced by $8.5 \%$. This is worthy of note that crude oil pollution increased bulk density and reduced total porosity. This also may result as blockage of pores spaces with the pollutant. [13] also reported a decrease in bulk density of soil polluted with spent lubricating oil when compared to a control.

Macroporosity: Crude oil pollution did not influence macroporosity at different profile depths (Table 2). Although similar results were obtained for polluted and unpolluted sites, macro porosity of the soil decreased 
with the presence of pollutant. This is an evidence of clogging of the pore spaces with crude oil. This may serve as impediment for air and water flow within the soil.

Generally, there was no significant interaction between crude oil pollution and depths of soil sampling. This indicates that crude oil pollution did not have direct relationship with depths of soil sampling.

\section{Conclusion}

The result of physical properties analyzed from soil samples from polluted sites show slight differences compared to the results from an unpolluted soil profile as a result of crude oil pollution in the area. The result revealed that physical properties of the soil that may be really affected are saturated hydraulic conductivity, macroporosity, total porosity and bulk density of the soil. All these properties are controlled by the pores spaces that are present in the soil. There may be need to do on-site experiment in order to ascertain some physical properties such as infiltration of water into the soil that can be affected by crude oil pollution. There was restriction in soil sampling beyond the depth of $15 \mathrm{~cm}$ as a result of hard pan formation from crude oil and soil which served as a constraint in the study area.

\section{Acknowledgements}

The author thank Mr. Akinpelu Shola from the PPMC, NNPC, Warri,Edo state of Nigeria for securing permission in order to have access to the sampling sites. The author would also like to thank Dr. Oshunsanya Suarau from the University of Ibadan for his assistance in the laboratory analysis

\section{References}

[1] Pepper, L. L., Gerbal, C.P., Brusseau, M.L., 1996. Pollution Science, Academic Press.

[2] Odu, C. T. L., 1997. Microbiology of soils contaminated with petroleum hydrocarbons Natural rehabilitation and reclamation of soil affected. Inst. Petroleum@, Technol., Publ.1,77-105.

[3] Marinescu, M., Toti, M., Tanase, V., Plopeanu, G., Calciu, I., Marinescu, M., 2001. The effects of crude oil pollution on physical and chemical characteristics of soil. Resaerch Journal of Agricultural Science, 43(3), 125-129.

[4] Engelking, P., Pollution, Microsoft Encarta Online Encyclopedia, 2000.

[5] Nwilo, P. C., Badejo, O.T., 2005. Impacts and Management of Oil spill Pollution along the Nigerian coastal area.flawww.fig.net/pub/fig pub/pub36/chapters/chapter-8pdf.

[6] Udo, E. J., Fayemi, A. A., 1975. The effect of oil pollution of soil on germination, growth and nutrient uptake of Corn. J. Environ. Qual., 4: 537-540.

[7] Okpowasili, G. C, Odokuma, L.O., 1990. Effect of Salinity on Biodegradation of oil spills dispersants. Waste Manage. 10(12) 141146.

[8] Gee, G. W, Or, D., 2002. Partide size distribution. In: Dane, J. H, Topp, G. C. (Eds.). Methods of Soil Analysis, Part 4. Physical Methods. SSSA, Inc., Madison, WI, pp. 255-293

[9] Reynolds, W. D., Elrick, D. E., Young's, E. G., Bobolink, H. W. G., Bouma, J., 2002. Soil water $\quad$ content: In :Dane, J.H, Topp, G.C.(Eds.).Methods of Soil Analysis, Part 4.Physical methods. SSSA, Inc., Madison, WI, pp. 802-817.

[10] Grossman, R. B., Reinsch, T.G., 2002. Bulk density and extensibility: Core method. In: Dane, J.H, Topp, G.C. (Eds.).Methods of Soil Analysis, Part 4.Physical Methods. SSSA, Inc., $\quad$ Madison, WI, pp. 208-228.

[11] Flint, L. E., Flint, A. L., 2002. Porosity. In: Dane, J. H, Topp, G. C. (Eds.). Methods of Soil Analysis, Part 4.Physical Methods. SSSA, Inc., Madison, WI, pp. 241-254.

[12] SAS Institute, 2002. SAS/STAT User's Guide. In : Version 8.2., SAS Institute Cary, NC.

[13] Kayode, J., Oyedeji, A. A., Olowoyo, O., 2010. Evaluation of the Effect of Pollution with Spent Lubricating oil on the Physical and Chemical Properties of Soil. Pacific Journal of Science and Technology 10 (1), 387-391.

Table 1. Effects of crude oil pollution on particle size distribution of soil at different depths $(\mathrm{cm})$ of

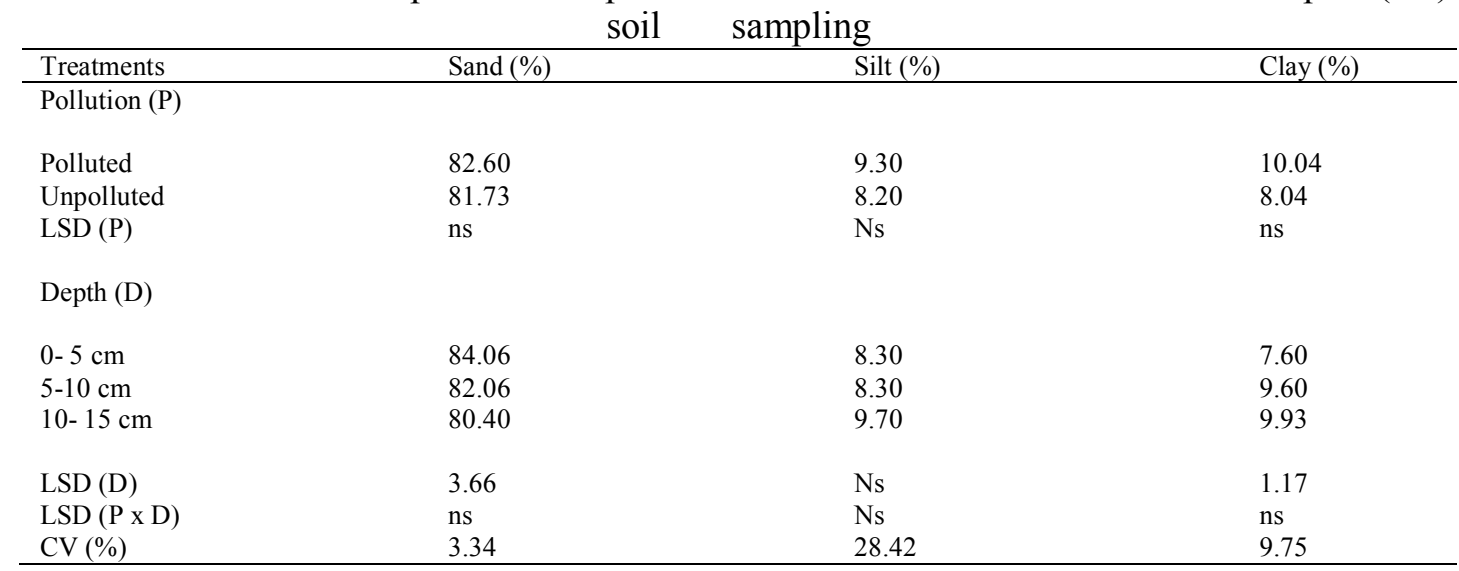

ns -no significant difference between treatment means $(\mathrm{p}<0.05)$; CV- coefficient of variability 
Table 2. Effects of crude oil pollution on other physical properties of soil at different depths $(\mathrm{cm})$ of soil sampling

\begin{tabular}{|c|c|c|c|c|c|}
\hline Treatments & $\begin{array}{l}\text { Saturated hydraulic } \\
\text { conductivity } \\
(\mathrm{cm} / \mathrm{hr})\end{array}$ & $\begin{array}{l}\text { Water holding } \\
\text { capacity } \\
\left(\mathrm{cm}^{3} / \mathrm{cm}^{3}\right)\end{array}$ & $\begin{array}{l}\text { Bulk density } \\
\left(\mathrm{Mg} / \mathrm{m}^{3}\right)\end{array}$ & $\begin{array}{l}\text { Total porosity } \\
(\%)\end{array}$ & $\begin{array}{c}\text { Macroporosity } \\
(\%)\end{array}$ \\
\hline \multicolumn{6}{|l|}{ Pollution (P) } \\
\hline Polluted & 0.03 & 44.18 & 1.40 & 0.47 & 21.60 \\
\hline Unpolluted & 0.02 & 40.30 & 1.30 & 0.51 & 26.20 \\
\hline LSD (P) & ns & ns & Ns & ns & ns \\
\hline \multicolumn{6}{|l|}{ Depth (D) } \\
\hline $0-5 \mathrm{~cm}$ & 0.04 & 46.10 & 1.30 & 0.53 & 22.90 \\
\hline $5-10 \mathrm{~cm}$ & 0.02 & 46.30 & 1.30 & 0.50 & 26.70 \\
\hline $10-15 \mathrm{~cm}$ & 0.03 & 34.40 & 1.35 & 0.50 & 22.10 \\
\hline LSD (D) & ns & ns & Ns & ns & ns \\
\hline $\operatorname{LSD}(\mathrm{P} \times \mathrm{D})$ & ns & ns & Ns & ns & ns \\
\hline CV $(\%)$ & 134.29 & 31.58 & 11.69 & 11.23 & 33.47 \\
\hline
\end{tabular}

ns -no significant difference between treatment means $(\mathrm{p}<0.05)$; CV- coefficient of variability 